\title{
GROOVED METAL VESSELS FROM THE ROMAN PERIOD COMMENTS ON THE VARIABILITY AND CONTEMPORARY STATE OF RESEARCH
}

KEYwORDS: Roman metal vessels; grooved toreutics; Roman Period

KLíčovÁ SLOva: Rímské kovové nádoby; žlabkovaná toreutika; doba římská

The issue of bronze/brass grooved toreutics from the Roman period is a popular topic of metal vessels research. This paper briefly summarizes contemporary knowledge about this theme and highlights the genesis and variability of the studied group of artefacts. This paper is based on the research of grooved ware which took place at Moravia and the Upper Danube part of Lower Austria (Jílek 2012: 44-48). This research has added, enlarged and also actualized the distribution map of archaeological finds from the region of former Czechoslovakia and the Upper Danube part of Lower Austria (Fig. 1). Attention will not be paid to the function of metal vessels, because a specialized study has been recently published (Hrnčiarik 2013) scrutinizing this problem in detail.

\section{Grooved BUCKETS}

Moravian and the Lower Danubian finds come from cremation burials from Bučovice (Beninger, Freising 1933: 21, 61, Tab. III: 1, 2; Tejral 1967: 92-93, Fig. 3: 1-10; Droberjar 2002: 37), Šitbořice (grave 6) (Droberjar, Kazdová 1993: 107, 146, Tab. 2: 6, 9; Tejral 1967: 91, 92, 128; 1970, 405; Droberjar 2002: 326, 327), Baumgarten an d. March (grave 5) (Adler 1976: 5, 7, Abb. 7; Tejral 1999: 175-182), Jevíčko (disturbed graves) (Fig. 2:3-7) (Droberjar, 
Vích 2011: 25, obr. 3) and newly also from a settlement at Vlčov - Dolní Němčí (Zeman 2014: obr. 5:1) and settlements at Prosiměřice and Borotice (Tejral 2015: 71, Fig. 24: 1,3).

The published members of this group from Bohemia were found only in Třebusice (grave XXIX/62) (Motyková-Šneidrová 1967: Tab. XI: 11; Sakař 1970: 50; Karasová 1998: 20). In Slovakia, a whole bucket was excavated at Dvory nad Žitavou (Ruttkay 2004: 155, 156, obr. 120:4; Hrnčiarik 2013: Tab. XVII: 1530), and vessel fragmets were also discovered at Očkov (grave 117) (Kolník 2004: Abb. 9:p1, p2), Abrahám, in disturbed burials, (Kolník 1980: 80, Tab. LXVII: 5) and in grave 3 (2/61) at Gbelce - Tehelňa (Fig. 2:2) (Beljak, Kolník 2006: 85-87, fig. 10).

Fragments from Bučovice and Šitbořice were ascribed to Eggers type 44 by J. Tejral $(1967: 90,92)$ based on the fine cannelation. Similarly, it is possible to evaluate the find from Dvory nad Žitavou (Hrnčiarik 2013: 100). The buckets from Baumgarten and Třebusice can be categorized as type E 47 (Adler 1976: 5, 7; Sakař 1970: 50). However, a problem occurs when connecting fragments to particular Eggers types of grooved vessels. We consider classification of fragments in accordance with types established by G. Ekholm ${ }^{1}$ (1935: 71-87) acceptable. The artefacts from the region belong to the Gile and Valløby types. Gile type is characterized by fine true cannelation, whilst Valløby type is characterized by wide and flat grooves closed by roof - like terminals (Tejral 1970: 397). According to these signs, the findings from Bučovice, Šitbořice, Jevíčko, Gbelce - Tehelňa and Dvory nad Žitavou belong to Gile type and bucket fragments from Baumgarten and Očkov fall into Valløby type.

\section{Grooved BowLS}

We know only several pieces of this variable vessel group from former Czechoslovakia. A bowl handle, type E 77, was found in disturbed burials at Stehelčeves. The handle could be generally dated to the late period of this cemetery outlined by phases B2b, B2/C1 and C1a (Motyková 1981; Karasová 1998: $24,80)$.

In Slovakia, a bowl (E 108) was documented in chieftain's grave I at Krakovany - Stráže (Hrnčiarik 2013: 54, 70, Taf. XXXIX:1047) and a bowl handle attachment of the same type at the settlement in Kostolište (Fig. 2:1) (Elschek, Marková 2000: 57, 61; Hrnčiarik 2013: 21, Tab. XL: 210).

\footnotetext{
${ }^{1}$ Contrary to G. Ekholm, we do not grant a chronological importance to the single types.
} 


\section{VARIABILITY AND CHRONOLOGY}

Origin of grooved decor can be traced already in the Hellenistic period (Pernice 1925: 17; Tejral 1970: 397). This technique is not only limited to buckets, but bowls, dishes and high vases were also frequently decorated. The described decoration is also known from the surface of silver vessels belonging to contexts of different age ${ }^{2}$. Early examples of grooved decoration, applied mostly on bronze and silver shell - shaped bowls/dishes, were already documented in the material from Pompeii (Willers 1907: 72, Abb. 41:11; Radnóti 1966: 207; Tassinari 1993: 169-173, N1100-N2300; Bienert 2007: 188-191, 200-203). Therefore, we can say that disccused decoration style had been known for a long period of time, and it can be definitely placed before year $79 \mathrm{AD}$.

Increase in the amount of grooved vessels can be observed from the half of the $2^{\text {nd }}$ century AD. The oldest types of buckets (E 44-49) and bowls (E 77) from the Roman provinces are dated to this period. We are talking especially about two graves from the Rhineland with grooved vessel, grave no. 3 from Gle$\mathrm{sch}^{3}$ (Willers 1907: 55, Abb. 33) and a grave find from Nijmegen (Willers 1907: 55; Werner 1936: 402) in particular. Fragments are also known from the sites found at the Upper-German - Raetian Limes ${ }^{4}$. These fragments, however, come from later contexts providing only ante quem datation (Werner 1939: 192-193; Eggers 1955: 46, 47; Tejral 1970: 398). A handle and two handle attachments of E 47-48 - type gooved bucket were excavated from disturbed inhumation grave B 13 at Vienna. The grave is dated to the $4^{\text {th }}$ century (Kronberger 2005: 148, Abb. 49), but the datation of the grave is based purely on context (position of the grave at the cemetery). It is important to interpret the bucket fragments in grave B 13 as evidence of the long-term use. The examples of grooved buckets from the Barbaricum are, in the most cases, categorized to phase B2/C1 (Tejral 1970; $1999 ; 2006: 152,155, \mathrm{Abb} .25)$, therefore to the end of the $2^{\text {nd }}$ century and at the beginning of the $3^{\text {rd }}$ century. However, they could occure in phase Cla (Tejral 2006: 155), even in phase C1b and exceptionaly in phase C2 in Scandinavia (Lund Hansen 1987: 62-64).

\footnotetext{
${ }^{2}$ For example a shell - shaped bowl from Casa del Menandro (Strong 1966: 153, Pl. 42A), a grooved vessel from Louvre inv. no. DJ 2370, a grooved bowl with omega - shaped handles from the hoard at Mildenhall (Painter 1975: 6, Abb. 8).

${ }^{3}$ The grave is dated to the second half of the $2^{\text {nd }}$ century.

${ }^{4}$ A handle attachment of a grooved bucket was excavated also at Rottweil. Unfortunately, without the closer finding circumstances (Flügel 1994: 217, Abb. 3: 13).
} 
We cannot list all the grave assemblages from the Barbaricum, but the finds of the Przeworsk culture are worth mentioning (Abramek 1982: 173, 178, Ryc. 4: b; Wielowiejski 1985: 270, 273-274). The described finds are present in abundance in the region of the Wielbark culture (Rudnicka, Mączyńska 2002; Mączyńska, Rudnicka 2004: 421-422; Natuniewicz-Sekuła, Okulicz-Kozaryn 2011: 65-67, 130, Pl. LXXXIII-LXXXV; Walenta 2009: 11-12, Tab 1. VII:1), Denmark and Scandinavia (Karasová 1998: 20; Lund Hansen 1987: 62-64).

Examples of grooved E 77 - type bowls are known from Belgian barrows in Tirlement - Tienen - Avendoren ${ }^{5}$ (Fig. 3:3) (Radnóti 1966: 207, 208; Wielowiejski 1985: 191, 195; Künzl 1993: 251; Stary 1991: 107, Abb. 13-16), Walsbetz (Werner 1936: 404) and from the Roman cemetery at Geldermasen in the Netherlands (Kunow 1983: 21). A Traian's coin was found in the Tirlement - Tienen - Avendoren barrow (Radnóti 1966: 207, 208; Petrovszky 1993: 327) which gives us post quem datation for this type of bowls. The grave is dated to the last quarter of the $2^{\text {nd }}$ century (Wielowiejski 1985: 195). Two pieces of newly published grooved bowls were excavated in the Roman Period cemetery at Heidelberg (Fig. 3:5, 7) (graves 62/P4, 65/113). Burial 62/P4 falls into phase I (80/85-115/120) and grave 65/113 with a bowl of type Bienert 76B is from phase 2 (1) (115/120-150/155) (Hensen 2009: 48, 370, 654,Tab. 224-65/113:1, 502-62/P4: 2, 4).

The Middle Danubien evidence also provides essential chronological informations. A grooved bowl with omega - shaped handles was a part of a hoard from Wels, deposited at the end of the $2^{\text {nd }}$ century or at the beginning of the $3^{\text {rd }}$ century (Miglbauer 1994: 291; Sedlmayer 1999: 159; Tejral 1999: 182). This find indicates the occurence of these bowls at the end of the $2^{\text {nd }}$ century. A Bienert 80 - type grooved bowl was also found in grave no. 78 at Linz-Kreuzschwestern. The aforementioned burial contained a Hadrian's coin (Sedlmayer 1999: 65-66, Abb. 9, Tab. 27:2). B. Bienert (2007: 191, 203) classifies bowls (type 80) to a wide range stretching from the Flavian period to the end of the $2^{\text {nd }}$ century. A rich grave from Halbturn in Pannonia represents another oftenly quoted example. In the grave, there were fragments of a E 77 - type bowl, and the grave was dated into the $1^{\text {st }}$ half of the $3^{\text {rd }}$ century (Radnóti 1966: 206-208, 213). There is also an important find of a grooved bowl from grave 68 at Intercisa in Pannonia. The period, when the bowl was put into the grave, is delimitted by the end of the $2^{\text {nd }}$ century and the beginning of the $3^{\text {rd }}$ century (Radnóti 1957: 181-182).

${ }^{5}$ The bowl beares stamp TR/I/C which can be read as ET RCC (Fig. 3:3) (Radnóti 1966: 207; Petrovszky 1993: 327). The group of these stamps, named by R. Petrovszky as Z 15, is known also from the numerous examples of bowls type E 78/79. 
Likewise, it is worth mentioning a newer find of a E 77 - type bowl at canabae legionis in Singidunum. The layer, from which the bowl comes, is dated to the end of the $2^{\text {nd }}$ century and to the $3^{\text {rd }}$ century (Vujovic 1997: 16-17, Fig. 1-5).

Wide popularity of "grooved ware" could be also documented by records from the provinces of the Lower Danube. Good examples are assemblages of different types of grooved vessels in the rich grave at Balčik (Škorpil 1912: 118, Abb. 94-95; Raev 1978: 627-628), the cremation grave at Mādrec (Fig. 3:4) and grave no. 2 at Lüleburgaz (Raev 1978: 627, 638, Taf. 19:5). The grave from Mādrec is dated by B. A. Raev (1978: 632-633) to the transition of the $1^{\text {st }}$ and $2^{\text {nd }}$ century, and H. Bujukliev (1983: 33) dated Mādrec grave to the half of the of the $2^{\text {nd }}$ century. The burial from Lüleburgaz is dated to the half of the $2^{\text {nd }}$ century and the rich grave from Balčik is from the transition of the $2^{\text {nd }}$ and the $3^{\text {rd }}$ century. The Limes hoards provide a certain evidence from 235-259/260. Even this context could provide different types of grooved bowls. Although, it is difficult to determine, whether the bowls were still manufactured in this period, or if these bowls were rather "antiquarian" vessels which had been manufactured in the previous period and still in use in the subsequent period. We are talking about examples from Rheinzabern-Germersheim (Werner 1938: Tab. 114:3; Tejral 1970: 397), Martigny, Filzen (Bienert 81) ${ }^{6}$ (Werner 1938: 109:6, 119:17) and Neupotz (Künzl 1993: 251-252). An interesting fact is that these hoards contain only grooved bowls, but there are no buckets. This fact is bewildering especially in the light of the generally accepted consensus stating that both bowls and buckets were manufactured at the same time. R. Petrovszky's hypothesis (1993: 127, 128) could provide an explanation. He argues that grooved buckets should have been replaced by the Hemoor type buckets, and it can be said that the upper limit of the occurence of E 77 - type bowls is hithero defined by the finds from these hoards dated into the period around the half of the $3^{\text {rd }}$ century. E 77 - type grooved bowls are present both in phase B2/C1 and in, chronologically later, phases $\mathrm{C} 1 \mathrm{a}, \mathrm{b}$. Rich cremation burial at Altengottern in the North-West Thuringia from the end of second century (Walther 2008a: 238-241; 2008b: 137, 139-140, Abb. 6) could be an example, belonging to the group of newer finds. The later presence of E 77 - type bowls is linked to the finds from Scandinavia (Lund Hansen 1987: 61).

Bowls of type E 108 belong to the later (chronologically interesting) kind of grooved toreutics. They are also known as Boesterd 196 - type, which is ussually dated to the $3^{\text {rd }}$ century, particulary to its first half (Lund Hansen 1987:

${ }^{6}$ B. Bienert (2007: 206) dates the hoard from Filzen to the chronological period between the $4^{\text {th }}$ and the $5^{\text {th }}$ century. 
86-87). The finds from this period are also known from grave no. 3 at Wehringen (aroud the year 250) (Nuber, Radnóti 1969: 43, 44, Abb. 10), Nijmegen museum $^{7}$ (Boesterd 1956: 57, 58, Pl. VIII: 196) and grave 1949/I at Himlingøje (Lund Hansen 1987: 85-87, another sites are listed here). At the settlement of the Roman Period Kostolište in Slovakia, there was a handle attachment in the shape of Seilenos mask (Fig. 2:1) (Elschek, Marková 2000: 57, 61; Hrnčiarik 2013: 21, Tab. XL: 210). Handle attachments of type E 108 are characteristic by two rings serving for attaching handles. K. Hoffmann showed (2004: 123, 206, Tab. 39:6) an analogical artefact from the settlement at Ochsenfurt-Hopferstadt (Fig. 3:6) in Bavaria, and she categorized it to the $3^{\text {rd }}$ century. Handle attachments could be decorated by the masks of Seilenos (Kostolište, Ochsenfurt-Hopferstadt), Pans (Wehringen, Himlingøje) and Maenads (Nijmegen museum). The bowl from grave I at Krakovany-Stráže (Ondrouch 1957: 103, obr. 22; Klčo, Krupa 2003: 13) can belong to type E 108, but the bowl is slightly different from the aforementioned ones due to differently shaped grooves and ring-shaped stem.

A grooved vessel found in the hoard excavated between Aldbrough and Knarsborough is an example of the later types. The deposited assemblage is dated to the $4^{\text {th }}$ century ${ }^{8}$ (Eggers 1968: 91, Abb. 42). The bowl represents an advanced example of grooved toreutics and shows considerable popularity of these decoration techniques. B. Bienert (2007: 204-206) collects more evidence of advanced occurence of Bienert 81 - type bowls in the Roman West, and he does not rule out their production in the $4^{\text {th }}$ century, and their usage in the $5^{\text {th }}$ century. However it has to be considered that these vessels, deposited mostly in graves, could be antiquities. A luxury silver grooved bowl with the omega-shaped handels, which was a part of the elite grave at Sutton Hoo, is a good example of the strong production tradition. This bowl was also an antiquarian piece made during the $5^{\text {th }}$ and the $6^{\text {th }}$ century in Italy (Quast 2011: 256-257, Fig. 3).

Rather specific kinds of grooved buckets were found in grave number 166 from the cemetery at Aquincum - Aranyhegyi-árok (Radnóti 1938: 121, Taf. XXXIV 3-4) which is also dated to the half of the $2^{\text {nd }}$ century (Radnóti 1957: 182). These vessels are morphologically different from Gile and Valløby types and their shapes are similar to type E 51. However, they are not entirely identic to type 51 because of the difference in grooves orientation and the shape of the rim. E 51 - type buckets are rare in the Barbaricum. H. J. Eggers (1951: 85, 165) registrated a piece from grave I at Gunnerupgaard from phase C1b (Lund

\footnotetext{
${ }^{7}$ The authoress also considers the datation of the finds to the $4^{\text {th }}$ century.

${ }^{8}$ The late variants of E 161 - type strainers and also the aforementioned grooved bowl draw our attention to this datation.
} 
Hansen 1987: 83, 412). A bowl similar to type E 51 was identified in the inventory of (most of the inventory has been lost) bronze vessels from the site Serby in Lower Silesia (Wielowiejski 1998: 129, 131, Ryc. 1). An E 51 - type bucket comes from the barrow at Tirlement-Tienen (Fig. 3:1) (Stary 1991: Abb. 13), the datation of this grave has been mentioned above. The cemetery at Starigrad in Croatia also provides an example similar to the buckets from Aquincum. The cemetery is dated to the period before the $2^{\text {nd }}$ century (Radnóti 1938: 121-122, Taf. XXXIV 2). The bucket very similar to the panonian grooved buckets (Raev 1978: 629, 639, Taf. 34:1) was found in grave I at Smočan in Moesia. The grave is probably also from the half of the $2^{\text {nd }}$ century ${ }^{9}$ (Raev 1978: 633; Dinchev 1997: 44-45). A bucket, similary shaped as the analogical bucket from Smočan, was excavated from the grave at the Serbian site Guberevac (Fig. 3:2). The burial is chronologically categorized according to the presence of a clay lamp with the stamp OCTAVI to the $2^{\text {nd }}$ century (Ratkovic 2005: 168-169, cat. 48). A bucket/ bowl with the ornamet of alternating eliptic lids and ribs found at Saône river from the $2^{\text {nd }}$ century to $3^{\text {rd }}$ century is close to this varied group of vessels (Baratte a kol. 1984: 104, Pl. LI:159, LXXIV:159). It is clear from the facts stated above, that grooved vessels close to type E 51 were known already around the half of the $2^{\text {nd }}$ century and their usage continued in the $3^{\text {rd }}$ century.

\section{INFLOW TO THE BARBARICUM}

Searching for a probable path of spreading is commonly investigated problem related to grooved toreutics. The spreading of the buckets along the Amber Road from Middle Danube Territory to the north (Tejral 1970: 397; 1999: 178, 181; 2006: 152), and along the sea way beginning in the Lower Rhine region (Werner 1936: 407; Wielowiejski 1985: Petrovszky 1993: 127) are considered. Therefore, the sea way should supply Danish islands, the East Pomerania, the Northen Poland and, according to R. Petrovszky (1993: 127), even the region of the Przeworsk culture. J. Tejral (1999: 178, 181; 2006: 152-154, Abb. 25) recently reacted on the argument favouring the sea way by introducing strong arguments in favour of the Amber road. He argued that the Amber road played an importat role in period B2/C1. Particularly, the sites from Silesia represents a link between Middle Danubian sites and the evidence from the north. Moreover, new finds from Jevíčko (Droberjar, Vích 2011) enable to speculate about connection between the Danube area and the north via the Czech and Moravian borderlands.

\footnotetext{
${ }^{9}$ The author of this article does not have a complex publication at his disposal.
} 


\section{Conclusions}

Thus, if we summarize the aformentioned datation of grooved vessels finds from the Roman evidence, we are able to determine a chronological framework with the bottom line that can be drawn already in the $1^{\text {st }}$ century and the top chronological limit ranging between the $3^{\text {rd }}$ century and the $4^{\text {th }}$ century. The grooved decor is frequent in Italy. We mean Bienert 76D, 78 and 79 - type (Bienert 2007: 189-190, 200-202) shell - shaped grooved bowls which are known from the evidence excavated at towns under Vesuvius. These morphological shapes are still in use in the whole $2^{\text {nd }}$ century and some of them (type Bienert 78) continues to be used in the Late Roman Period. As has been already mentioned above, the occurence of grooved vessels in Limes hoards is difficult to interpret, and the question of manufacturing of these vessel around half of the $3^{\text {rd }}$ century is still opened. In the case of E 108/Boesterd 196 - type bowls, we can expect that they were fabricated perhaps in the $3^{\text {rd }}$ century. We can not rule out the usage of the later variants of grooved bowls in the $4^{\text {th }}$ century, as the evidence from the Roman Britain indicates. This ware is also known from the western provinces in the later archaeological contexts (Bienert 2007: 204-206).

A group of buckets found in Pannonia and Moesia belongs to the $2^{\text {nd }}$ century. This type of vessels is not present in the Pompeii evidence (Tassinari 1993). Thus, it can be assumed, as the state of research shows, that discussed examples were probably manufactured in the Balkan workshops (Radnóti 1957: 182-183; Ratkovic 2005: 169) and even in workshops in Greece towns at the Black Sea.

The rise in popularity of grooved toreutics in the West provinces from the half of the $2^{\text {nd }}$ century is confirmed by the finds from the Rhine region and the Belgian barrows. The end of production of buckets of type E 44-49 can be linked to the time period before the half of the $3^{\text {rd }}$ century especialy because of the absence of these vessels in the Limes hoards (Berke 1990: 48). The finds of grooved ware from the Barbaricum usually occur in archaeological assemblages from phases B2/C1, C1a (Tejral 1999), C1b (Wielowiejski 1985: 191, 193; Lund Hansen 1987: 61, 62-64, 85-87). Shell shaped bowls can be found also in stage C2 (Künzl 1993: 253).

There are different opinions about the location of production of $\mathrm{E} 77$ bowls and E 44-49 buckets. The author was not able to trace the evidence indicating workshops in archaeological contexts. Thus, consideration about the location of production sites are based on their distribution in the Roman Empire. According to older research, it is possible that grooved vessels (bowls and buckets) were manufactured in the same workshops (Werner 1936: 404). Z. Karasová 
(1998: 21), as the last author, stated a hypothesis about the origin of these vessels.

Resulting from this preliminary paper, grooved toreutics was spread in the Roman West and also in the Eastern areas. Therefore, we can only hardly restrict our efforts to find production centres to the only one production area. A certain argument, supporting the Gaulish and the Middle - Rhine provenance of grooved vessels, is based on the evidence of E 77 - type bowl from Tirlement - Tienen - Avendoren labeled with a stamp of the Gaulish origin. A. Radnóti (1966: 208) appropriately captures the problem of localization of production centres, stating that several production centres occured in the Roman Empire.

PhDr. Jan Jílek, Ph.D.

Univerzita Pardubice, Fakulta filozofická

Ústav historických věd

Studentská 84

53210 Pardubice

Česká Republika

Východočeské muzeum v Pardubicích

Archeologické oddělení

Zámek čp. 4

Pardubice 53002

Česká Republika

email: mitridates@post.cz

\section{BiBLIOGRAPHY}

Abramek B. (1982), Cmentarzysko ciałopalne kultury Przeworskiej w Konopnici na stan. 7, woj. Sieradz, „Sprawozdania Archeologiczne“, t. XXXIV, s. $171-182$.

Adler H. (1976), Kaiserzeitlische Funde aus Baumgarten an der March, „Mitteilungen Anthropologischen Gesellschaft Wien“, t. 106, s. 3-16.

Baratte F., et. al. (1984), Vases antiques de métal au Musée de Chalon-sur Saô ne, 5e supplement á la Revue Archéologique de l'Est, Dijon.

Beljak J,. Kolník T. (2006), Germánske hroby z Čaky a Gbeliec. Prispevok k osídleniu juhozápadného Slovenska v dobe rímskej, „Slovenská Archeológia“, t. LIV/1, s. 57-94. 
Beninger E., Freising E., H. (1933), Die Germanische Bodenfunde in Mähren, Reichenberg.

Berke S. (1990), Römische Bronzegefässe und Terra Sigillata in der Germania Libera, Boreas-Beiheft 7, Archäologisces Seminar der Universität Münster, Münster.

Bienert B. (2007), Die römischen Bronzegefässe im Rheinischen Landesmuseums Trier, „Trierer Zeitschrift Beiheft“, t. 31, Trier.

Boesterd M. H. P. (1956), The Bronze Vessels in Rijksmuseum, G. M. KAM at Nijmegen 20 , t. I, Nijmegen.

Bujukliev H. (1984), Tombeau tumulaire Thrace pres du village de Mādrec, departement de Stara Zagora, „Разкопки и проучания”, кн. 10, s. 7-33.

Dinchev V. N. (1997) Roman Villas in the Present-Day Bulgarian Lands, AGATO Press, Sofia.

Droberjar E. (2002) Encyklopedie ř́mské a germánské archeologie v Čechách a na Moravě, Praha.

Droberjar E., Kazdová E. (1993), Das Brandgräberfeld aus der römischen Kaiserzeit von Šitbořice in Mähren I. Die Quellen, „Časopis Moravského Muzea”, vědy společenské, t. 78, s. 97-149.

Droberjar E., Vích D. (2011), Nové žárové pohřebiště z doby ř́mské v Jevičku-Předměstí, okr. Svitavy, [in:] Archeologie barbarů 2010. Hroby a pohřebiště Germánů mezi Labem a Dunajem, ed. E., Droberjar, Univerzita Palackého, Olomouc, s. $23-38$.

Eggers H. J. (1951), Der römische Import im freien Germanien, Museum für Völkerkunde und Vorgeschichte, Hamburg.

Eggers H. J. (1955), Die römischen Bronzegefässe von der Saalburg, „Saalburg Jahrbuch” t. 14 , s. $45-49$.

Eggers H. J. 1968 Römische Bronzegefässe in Britannien, „Jahrbuch RGZM“, t. 13, s. $67-164$.

Ekholm G. (1935), Zur Geschichte des römisch-germanischen Handels, „Acta Archaeologica København”, t. 6, s. 49-98.

Elschek K., Marková K. (2000), Archeologický výskum a prieskum na Záhorí v záujmovom území podzemných zásobníkov plynu, „Archeologické výskumy a nálezy na Slovensku" 1998, s. 53-64.

Flügel CH. (1994), Römischen Bronzegefässe aus Arae Flaviae-Rottweil, „Fundberichte aus Baden-Württemberg”, t. 19, s. 207-217.

Hensen A. (2009), Das römische Brand- und Körpergräberfeld von Heidelberg I. 1 Katalog und Untersuchungen, Forschungen und Berichte zur vor und Frühgeschichte in Baden-Württemberg Bd. 108, Stuttgart.

Hoffmann K. (2004), Kleinfunde der römischen Kaiserzeit aus Unterfranken. Studien zur Siedlungsgeschichte und kulturellen Beziehung zwischen Germanen und Römern, Internationale Archäologie Bd. 80, Rahden/Westf. 
Hrnčiarik E. (2013). Römisches Kulturgut in der Slowakei. Herstellung, Funktion, und Export römischer Manufakturerzeugnisse aus den Provinzen in der Slowakei, Universitätsforschungen zur Prähistorischen Archäologie 222, Bonn.

Jílek J. (2012), Bronzové nádoby z doby řimské z Moravy a naddunajské části Dolního Rakouska, Univerzita Pardubice, Pardubice.

Karasová Z. (1998), Die römischen Bronzegefässe in Böhmen, „Archaeologici Pragenses", t. 22, Pragae.

Klčo M., Krupa V. (2003), German graves from roman times from Krakovany-Stráže, Balneological Muzeum, Piešt'any.

Kolník T. (1980), Römerzeitliche Gräberfelder in der Slowakei, „Archaeologica Slovaca Fontes", t. XIV, Bratislava.

Kolník T. (2004), Die mittledanubische Barbaricum - eine Brücke zwischen Zentrum und Peripherie am Beispeil medizinischen Messerfunde, [in:] Zentrum und Peripherie - gesellschaftliche Phänomene in der Frühgeschichte, eds. H. Friesinger, A. Stuppner, Verlag WÖAM, Wien, s. 195-210.

Kronberger M. (2005), Siedlungschronologische Forschungen zu den canabae legionis von Vindobona. Die Gräberfelder, Magistrat der Stadt Wien, Wien.

Kunow J. (1983), Die römische Import in der Germania Libera bis zu den Markomannenkriege. Studien zu Bronze- und Glassgefässe, Neumünster.

Künzl E. (1993), Die Alamannenbeute aus dem Rhein bei Neupotz. Plünderungsgut aus dem römischen Gallien, RGZM Monographien, Bd. 34, Mainz.

Lund Hansen U. (1987), Römischer Import in Norden, „Nordiske Fortidsminder”, Serie B 10, København.

Mączyńska M., Rudnicka D. (2004), Ein Grab mit römischen Importen aus Czarnówko. Kr. Lębork (Pommern), „Germania”, t. 82, s. 397-429.

Miglbauer R. (1994), Ein römerzeitlicher Verwahrfund aus Wels. Oberösterreich, [in;] Akten der 10. Internationalen Tagung über antike Bronzen, Freiburg 18.-22. Juli 1988, Forschungen und Berichte zur vor und Frühgeschichte in Baden-Württemberg, Bd. 45, Stuttgart, s. 285-291.

Motyková-Šneidrová K. (1967), Weiterentwicklung und Ausklang der alteren römischen Kaiserzeit in Böhmen, „Fontes Archaeologici Pragenses”, t. 11, Pragae.

Motyková K. (1981), Das Brandgräberfeld der römischen Kaiserzeit von Stehelčeves, „Památky Archeologické”, t. 72, s. 340-415.

Natuniewicz-Sekuła M., Okulicz-Kozaryn J. (2011), Weklice, A Cemetery of the Wielbark Culture on the Eastern Margin of Vistula Delta (Excavations 1984-2004), „Monumenta Archaeologica Barbarica”, t. 17, Fundacja MAB, Warszawa.

Nuber H. U., Radnóti, A. (1969), Römische Brand und Körpergräber aus Wehringen Ldkr. Schwabmünchen, „Jahresbericht der Bayerischen Bodendekmalpflege”, t. 10 , s. $27-49$. 
Ondrouch V., (1957), Bohaté hroby z doby rímskej na Slovensku, Vydavatel'stvo Slovenskej Akadémie Vied, Bratislava.

Painter K.-S. (1975), Der Schatz von Mildenhall, „Antike Welt”, t. 6, h. 1, s. 3-13.

Pernice E. (1925), Gefässe und Geräte aus Bronze. Die hellenistiche Kunst in Pompeji, Bd. IV, De Gruyter, Berlin-Leipzig.

Petrovszky R. (1993), Studien zu römischen Bronzegefässen mit Meisterstempel, Kölner Studien zur Archäologie der Römischen Provinzen, Bd. 1, Buch am Erlbach.

Quast D. (2011), Symbolic Treasures in Barbarian Burials (3rd-7th century AD), [in:] Oggetti-simbolo: produzione, uso e significato nel mondo antico, eds. I. Baldini Lippolis, A. L. Morelli, Ornamenta 3, Ante Quem, Bologna, s. $253-268$.

Raev B. A. (1978), Die Bronzegefässe der römischen Kaiserzeit in Thrakien und Mösien, „Bericht RGK” (1977), Bd. 58/2, s. 605-432.

Radnóti A. (1938), Die römischen Bronzegefässe von Pannonien, Dissertationes Pannonicae, Serie II, n. 6, O. Harrassowitz, Budapest-Leipzig.

Radnóti A. (1957), Gefässe, Lampen, und Tintefässer aus Bronze. Intercisa II, (Dunapentele), „Archaeologica Hungarica S.N.”, t. 36, s.173-193.

Radnóti A. (1966), Ein römisches Urnengrab in Halbturn (Burgenland), „Wissenschaftliche Arbeiten aus dem Burgenland", t. 35, s. 199-221.

Ratkovič D. (2005), Roman bronze vessels in the Roman collection of The National museum in Belgrade, Narodni Muzej, Belgrade.

Rudnicka D., Mączyńska M. (2002), Czarnówko, pow. Lebork. Grób 430 z importami rzymskimi, [in:] Varia Barbarica, red. J. Andrzejowski, R. Prochowicz, A. Żórawska, Monumenta Archaeologica Barbarica, Series Gemina, t. I, Warszawa-Lublin, s. 11-28.

Ruttkay M. (2004), Unikátny nález $z$ doby rímskej $v$ Dvorech nad Žitavou, „Archeologické výskumy a nálezy na Slovensku”, 2003, s. 155-156.

Sakař V. (1970), Roman Imports in Bohemia, „Fontes Archaeologici Pragenses”, t. 14. Pragae.

Sedlmayer H. (1999), Die römischen Bronzegefässe in Noricum, Monographies Instrumentum 10, EMM, Montagnac.

Stary P. F. (1991), Reiche Gräber der Zeitenwende beiderseits des Ärmelkanals, „Bonner Jahrbücher”, t. 191, s. 85-123.

Strong D. E. (1966), Greek And Roman Gold And Silver Plate, Meuthuen, London.

Škorpil K. (1912), Grabfund in Balčik, „Jahreshefte des Archäologischen Institutes in Wien", Bd. 15, s. 101-134.

Tassinari S. (1993), Il Vasellame Bronzeo di Pompei, L’Erma di Bretschneider, Roma.

Tejral J. (1967), K otázce importu bronzových nádob na Moravu ve starši době ř́mské, „Památky Archeologické”, t. 58, s. 81-134. 
Tejral J. (1970), Markomanské války a otázka ř́mského dovozu na Moravu po Commodově míru, „Archeologické Rozhledy”, t. 22, s. 389-411.

Tejral J. (1999), Die Völkerwanderungen des 2. und 3. Jhs und ihr Niederschlag im archäologischen Befund des Mitteldonauraumes, [in:] Das mitteleuropäische Barbaricum und die Krise der römische Weltreiches im 3. Jahrhundert, ed. J. Tejral. „Spisy Archeologického ústavu AV ČR Brno” sv. 12. Brno, s. 137-213.

Tejral J. (2006), Die germanische Giessereiwerkstatt in Pasohlávky (Bez. Břeclav). Ein Beitrag zur Frage der Fernhandels- und Kulturbeziehungen nach den Markomannenkriegen, „Památky archeologické”, t. XCVII, s. 133-170.

Vujović M. B. (1997), Dve bronzane posude iz Singidunuma, „Godišnjak grada Beograda“, t. 44, s. 11-17.

Walenta K. (2009), Leśno i mikroregion w okresie rzymskim, Muzeum HistorycznoEtnograficzne w Chojnicach, Chojnice.

Walther W. (2008a), Altengottern, Unstrut-Hainich - Kreis, [in:] Die Langobarden das Ende der Völkerwanderung. Katalog zur Ausstellung im Rheinischen Landes Museum Bonn, 22.8.2008-11.1.2009, ed. M. Hegewisch, Landschaftsverband Rheinland, Darmstadt, s. 238-241.

Walther W. (2008b), Ein reich ausgestattetes Brandgrab einer Elbgermanin aus dem späten 2. Jahrhundert n. Chr. von Altengottern, Unstrut - Hainich - Kreis (Nordwestthüringen), [in:] Kulturwandel in Mitteleuropa. LangobardenAwaren-Slawen, eds. J., Bemmann, M., Schmauder, Kolloquien zur Vorund Frühgeschichte Bd. 11, Bonn-Köthen, s. 127-144.

Werner J. (1936), Zur Herkunft und Zeitstellung der hemmoorer Eimer mit gewellten Kanneluren, "Bonner Jahrbücher”, t. 140/141, s. 395-410.

Werner J. (1938), Die römischen Bronzegeshirdepots des 3. Jahrhunderts und die mitteldeustche Skelettgräbergruppe, Marburger Studien, Darmstadt, s. 259-267.

Werner J. (1939), Ein Bronzeeimer mit gewellten Kanneluren von Einig, „Germania”, t. 23, s. 191-192.

Wielowiejski J. (1985), Die spätkeltischen und römischen Bronzegefässe in Polen, „Bericht RGK”, t. 66, s. 123-320.

Wielowiejski J. (1998), Rzymskie naczynia brazowe z Serbów na Dolnym Ślaşku, [in:] Nowe znaleziska importów rzymskich z ziem Polski, I, ed. J., Kolendo. Supp. Bd. I., Instytut Archeologii UW, Warszawa, s. 128-133.

Willers H. (1907), Neue Untersuchungen über die römische Bronzindustrie von Capua und von Niedergermanien besonders auf die Funde aus Deutschland und dem Norden hin, Hahnsche Buchhandlung, Hannover-Leipzig.

Zeman T. (in print), Germánská sídliště a pohřebiště ve Vlčnově - Dolním Němči na základě nových detektorových nálezů, „Slovácko”, t. LVI/2014. 


\title{
SHRNUTí
}

\author{
KOVOVÉ NÁDOBY ZDOBENÉ ŽLÁBKY Z DOBY ŘÍMSKÉ \\ POZNÁMKY K VARIABILITĚ A SOUČASNÉMU STAVU BÁDÁNÍ
}

Problematika bronzové/mosazné žlábkované toreutiky z doby římské patří k oblíbeným tématům bádání o kovových nádobách. Tento text stručně shrnuje současné poznání tématu a poukazuje na genezi a pestrost studované skupiny artefaktů. Vychází ze zpracování žlábkovaného zboží pro Moravu a naddunajskou část Dolního Rakouska (Jílek 2012: 44-48), které doplňuje a rozšiřuje, rovněž aktualizuje nálezovou mapu oblasti bývalého Československa a naddunajské části Dolního Rakouska (obr. 1). Pozornost nebude věnována funkci kovových nádob. Důvodem je nedávné vydání specializované práce (Hrnčiarik 2013), která se tímto problémem detailně zabývá.

\section{ŽLÁBKOVANÁ VĚDRA}

Moravské a dolnorakouské nálezy pochází ze žárových hrobů z Bučovic (Beninger, Freising 1933: 21, 61, Taf. III: 1, 2; Tejral 1967: 92-93, obr. 3: 1-10; Droberjar 2002: 37), Šitbořic (hrob 6) (Droberjar, Kazdová 1993: 107, 146, Taf. 2: 6, 9; Tejral 1967: 91, 92, 128; týž 1970, 405; Droberjar 2002: 326, 327), Baumgarten an d. March (hrob 5) (Adler 1976: 5, 7, Abb. 7; 1999: 175-182), Jevíčka (rozrušené hroby) (Droberjar, Vích 2011: 25, obr. 3) (obr. 2:3-7) a nově také ze sídliště z Vlčnova-Dolního Němčí (Zeman 2014: obr. 5:1) a sídlišt' z Prosměřic a Borotic (Tejral 2015: 71, Fig. 24:1,3).

Publikované zástupce této skupiny z Čech pak známe pouze z Třebusic (hrob XX-X/62) (Motyková-Šneidrová 1967: Taf. XI:11; Sakař 1970: 50; Karasová 1998: 20). Území Slovenska vydalo celé vědro z Dvorů nad Žitavou (Ruttkay 2004: 155, 156, obr. 120:4; Hrnčiarik 2013: Taf. XVII:1530). Zlomky nádob pak registrujeme v Očkově (hrob 117) (Kolník 2004: Abb. 9:p1, p2), z rozrušených hrobů v Abrahámu (Kolník 1980: 80, Taf. LXVII:5) a hrobu č. 3 (2/61) z Gbelců - Tehelňy (obr. 2:2) (Beljak, Kolník 2006: 85-87, obr. 10).

\section{ŽLÁBKOVANÉ MÍSY}

Z této variačně pestré skupiny nádob známe z území bývalého Československa pouze několik kusů. Z Čech pochází držadlo mísy typu E 77 z rozrušených hrobů ve Stehelčevsi. Držadlo je rámcově datováno do mladší fáze pohřebiště, která je ohraničena stupni B2b a B2/C1, C1a (Motyková 1981; Karasová 1998: 24, 80).

Ze Slovenska je doložena mísa E 108 z knížecího hrobu I v Krakovanech-Strážích (naposledy Hrnčiarik 2013: 70, Taf. XXXIX:1047) a ataše mísy téhož typu ze sídliště v Kostolišti (obr. 2:1) (Elschek, Marková 2000: 57, 61; Hrnčiarik 2013: 21, Taf. XL: 210). 
Pokud tedy shrneme uvedené datování nálezů žlábkovaných nádob z říšského materiálu, získáme jako spodní časový údaj již polovinu 1. století a jako vrchní rámcový chronologický ukazatel polovinu 3. století až 4. století. S časným výskytem žlábkování se tak setkáme v Itálii. Máme zde na mysli mušlovité žlábkované misky typu Bienert 76D, 78, 79 (Bienert 2007: 189-190, 200-202), které známe již z materiálu měst pod Vesuvem. Tyto tvary jsou dále užívány po celé 2 . století a některé (typ Bienert 78) až do mladší doby římské. Jak již bylo nastíněno výše, výskyt žlábkovaných mís v limitních depotech lze obtížně interpretovat a otázka výroby těchto nádob kolem poloviny 3. století zůstává doposud otevřená. V prrípadě mís typu E 108/Boesterd 196 lze snad počítat s fabrikací ve 3. století. Jak ukazují vzácné exempláře z provincie Británie, nelze vyloučit použivání pozdních variant žlábkovaných mís ani ve 4. století. Přičemž toto zboží je známé i ze západních provincií v mladších nálezových kontextech (Bienert 2007: 204-206).

Skupina věder nalezených v Pannonii a Moesii, se hlásí do průběhu 2. století. Tento typ nádob není zastoupen v pompejském materiálu (Tassinari 1993). Lze se tedy domnívat, jak ukazuje dosavadní stav bádání, že pojednávané př́klady byly pravděpodobně vyráběny v balkánských dílnách (Radnóti 1957: 182-183; Ratkovic 2005: 169) a snad i v dílnách řeckých měst na březích Černého moře.

Nálezy z Porýní a belgických mohyl potvrzují vzestup obliby žlábkované toreutiky v západních provinciích od poloviny 2. století. Konec produkce žlábkovaných věder typu E 44-49 lze hledat před polovinou 3. století, a to zvláště pro jejich absenci v limitních depotech (Berke 1990, 48). Nálezy žlábkovaného zboží z barbarika se vyskytují v nálezových celcích zpravidla zasazovaných do stupňů B2/C1, C1a, (Tejral 1999), C1b (Wielowiejski 1985: 191, 193; Lund Hansen 1987: 61, 62-64, 85-87). Žlábkované mušlovité misky i v kontextech datovaných do stupně C2 (Künzl 1993: 253).

O místě výroby žlábkovaných mís typu E 77 a věder typu E 44-49 panují rozličné názory. Doklady dílenských archeologických kontextů se autorovi nepodařilo vysledovat. Úvahy o místech výroby jsou tedy založeny na jejich prostorovém rozložení v impériu. Podle názorů staršího bádání je možné, že se žlábkované nádoby (mísy, vědra) vyráběly ve stejných dílnách (Werner 1936: 404). Naposledy byly hypotézy o původu těchto nádob uvedeny v práci Z. Karasové (1998: 21). Jak vyplývá z výše předloženého textu, žlábkovaná toreutika byla rozšířena jak na římském západě, tak v krajích východních. Těžko se tedy lze při hledání produkčních center omezovat pouze na jednu výrobní oblast. Jistý argument podporující galskou nebo středorýnskou provenienci žlábkovaných nádob představuje mísa typu E 77 z Tirlement - Tienen - Avendoren označená kolkem galského původu. Vhodně problém lokalizace výroby vystihl A. Radnóti (1966: 208), který předpokládal výskyt několika různých dílenských okruhů na území rrímské říše. 


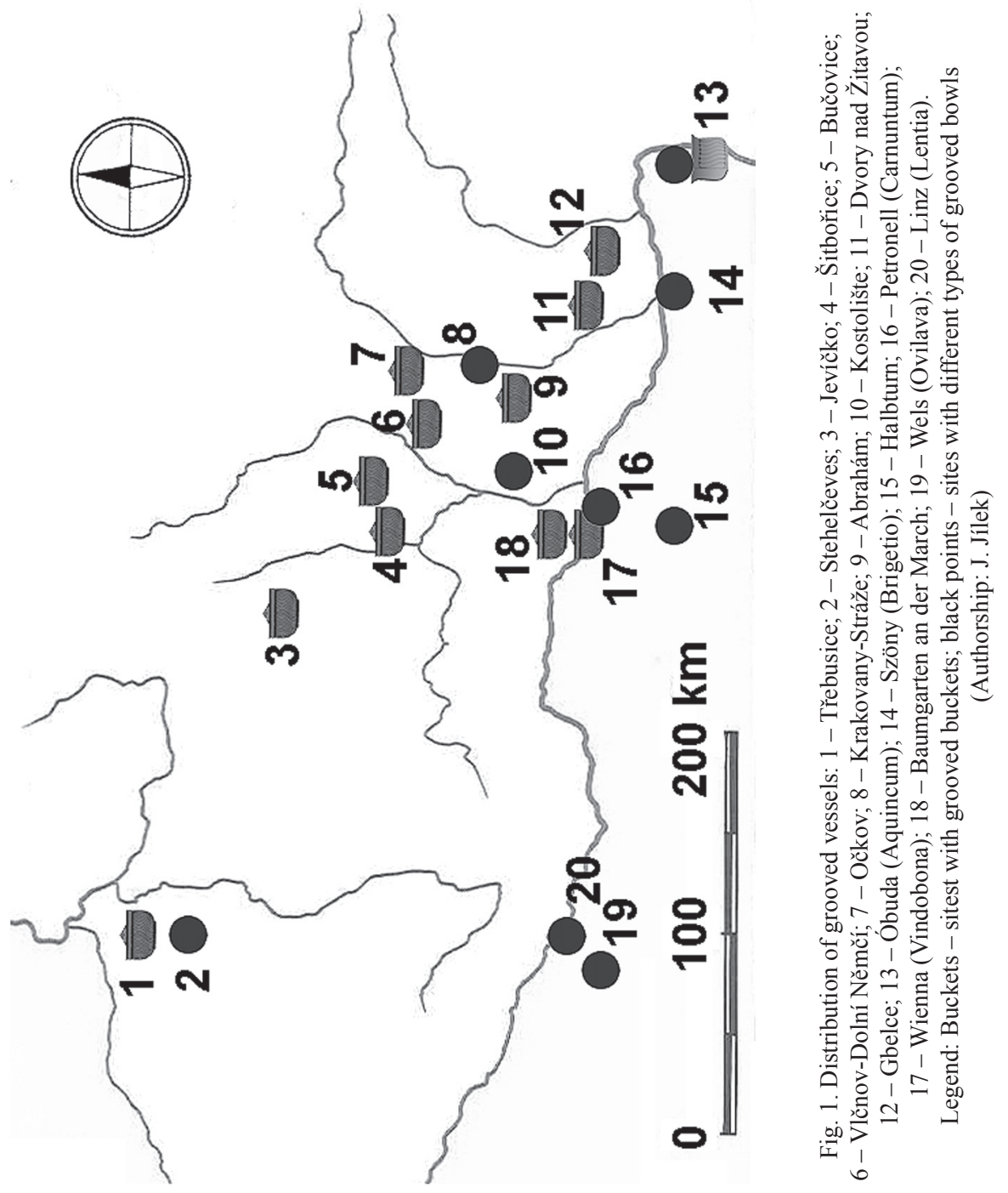



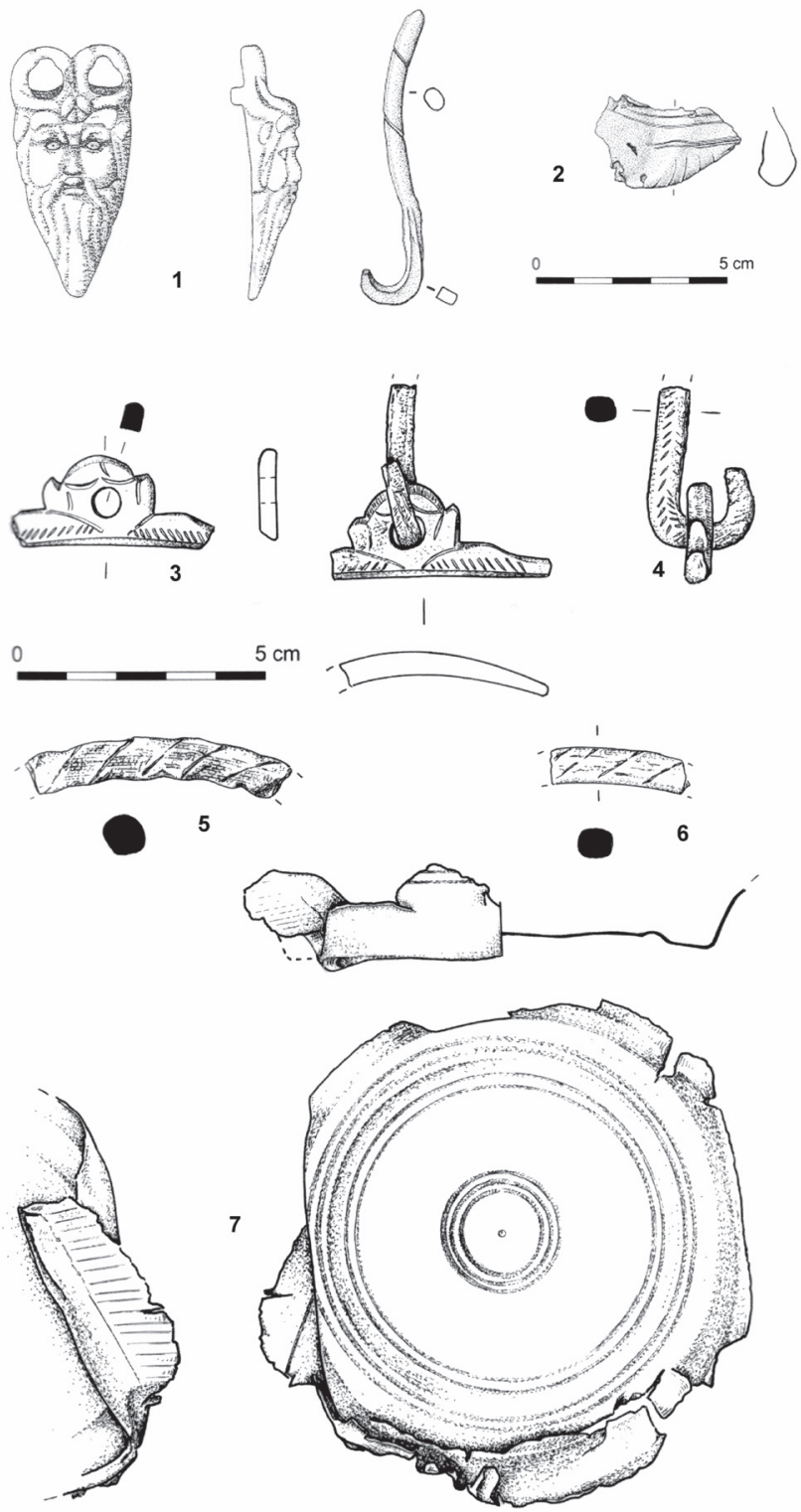

Fig. 2: 1 - Kostolište, distr. Malacky, handle attachment of bowl of Boesterd 196 type; 2 - Gbelce, distr. Nové Zámky, fragments of grooved bucket; 3-7 - Jevíčko, distr. Svitavy, fragments of grooved bucket (s)

(Source: 1 - Hrnčiarik 2013; 2 - Beljak, Kolník 2006; 3-7 - Droberjar, Vích 2011) 

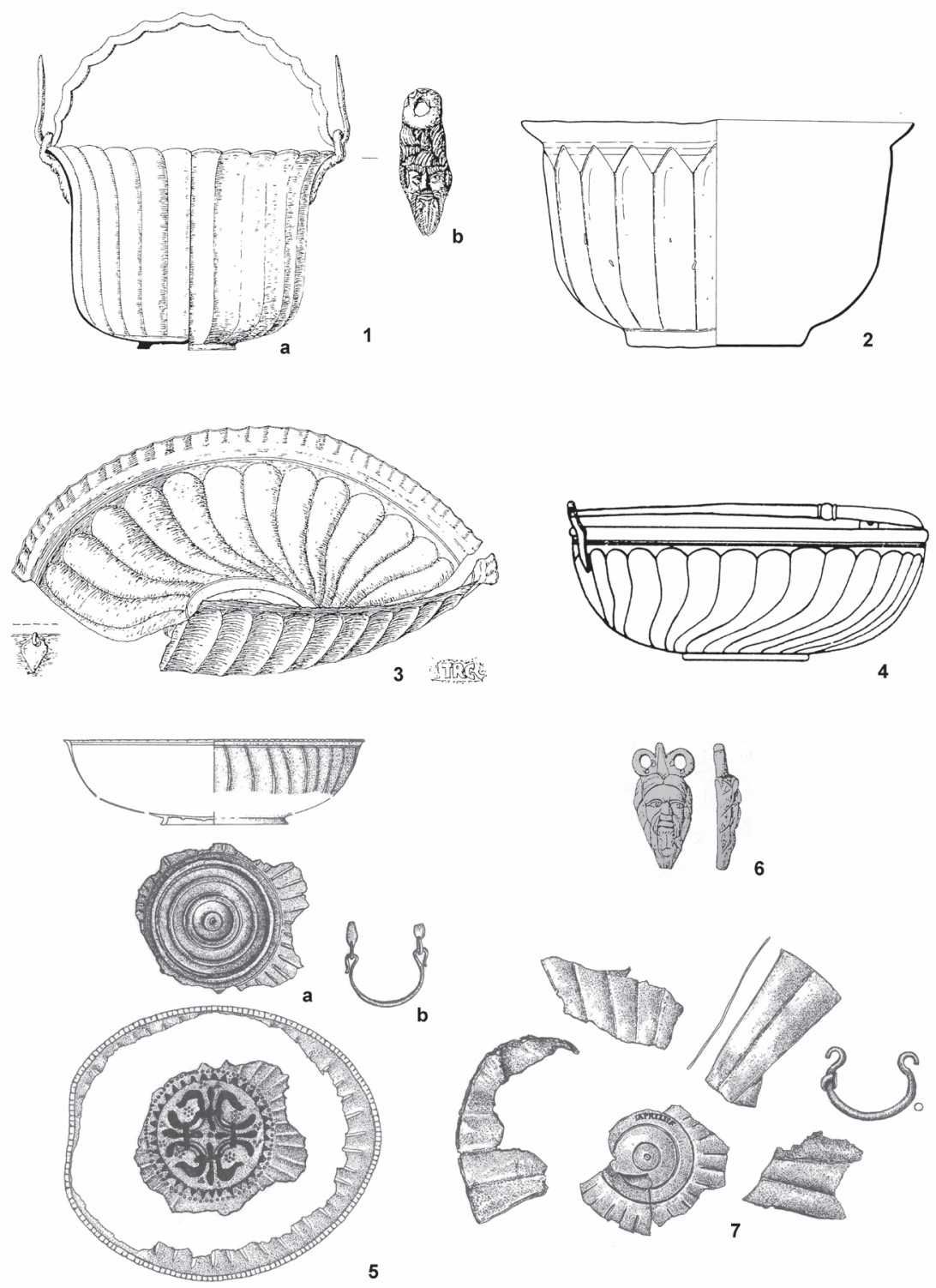

Fig. 3: 1 - Tirlement - Tienen - Avendoren, bucket of E 51 type;

2 - Guberevac, bucket of Raev 15 type; 3 - Tirlement - Tienen - Avendoren, grooved bowl; 4 - Mādrec, grooved bowl; 5 - Heidelberg I, grave 62/P4, fragments of grooved bowl; 6 - Ochsenfurt-Hopferstadt, handle attachment of bowl of Boesterd 196 type; 7 - Heidelberg I, grave 65/113, fragments of grooved bowl of Bienert 76B type (Source: 1, 3 - Stary 1991; 2 - Ratkovic 2005; 4 - Raev 1978; 5, 7 - Hensen 2009; 6 - Hoffmann 2004) 

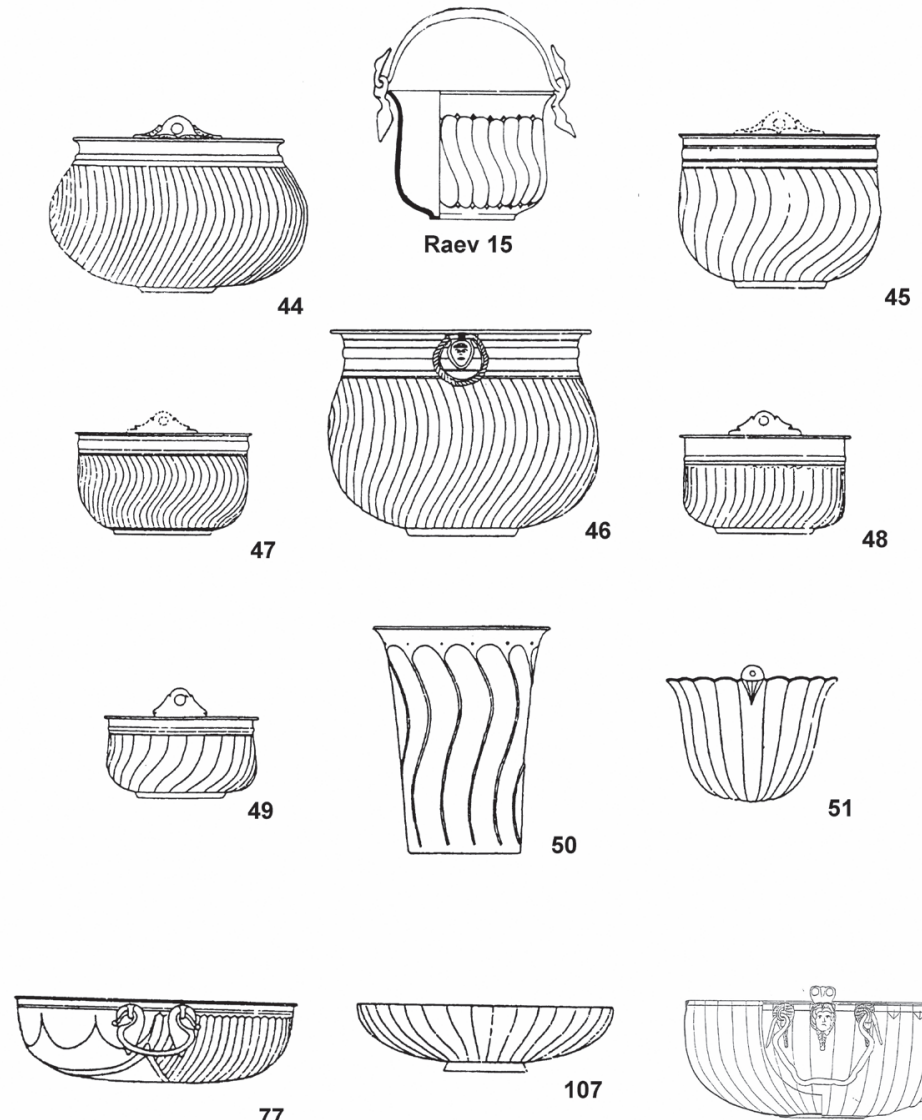

107
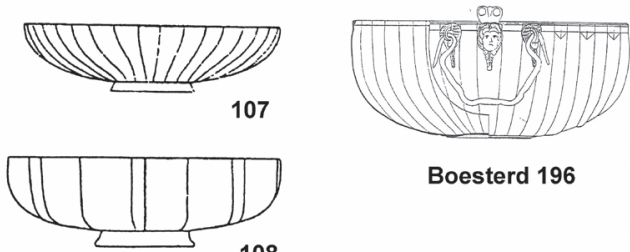

Boesterd 196

108

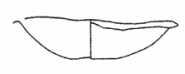

Bienert 76

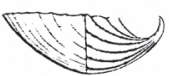

Bienert 78

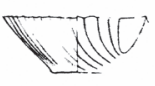

Bienert 79

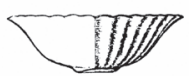

Bienert 80

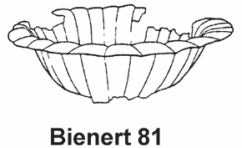

Bienert 81

Fig. 4. Main types of grooved vessels

(Source: Eggers 1951; Boesterd 1956; Raev 1978; Bienert 2007) 